\title{
HOT-WORKABILITY OF INCONEL 600 AND HASTELLOY X
}

\author{
M. SAKAKIBARA AND S. SEKTNO
}

Technical Research Inst., Yawata Works, Nippon Steel Corp. Kitakyushu, Japan

\section{SYNOFSIS}

The hot-workability of Inconel 600 and Hastelloy X was investigated, varying the melting practices, minor elements, impurities. It was clarified that it was improved by decreasing $\mathrm{Cu}$ and $\mathrm{Mn}$ content, by adding $\mathrm{B}, \mathrm{Be}$, Zr and $\mathrm{Ce}$, by decreasing inclusions, and by decreasing $\gamma$ grain size. The effective processes for its improvement were electro-slag remelting, refining under vacuun, diffusion-annealing, and increase of forging ratio.

\section{INTRODUCTION}

Superalloys are widely used because of thoir cxcollent properties at high temperature and in corrosive atmospheres. But there are many problems in the production as they have generally poor workability. To expand their uses to larger and longer products, it is necessary to improve the hot-workability. The factors which control the hot-workability, seem to be the ductility of alloys themselves, the strength of $\gamma$ grain boundaries (1), inclusions(2), precipitates, segregations(3), and impurities which generally relate intimately to grain boundaries. These factors depend upon the chemical composition, casting conditions, deformation condilions dra heal-treatinents ete. We examined in this report, the effect of production processes on the hotworkability of Tnconel 600 and Hastelloy $X$.

\section{EXPERIMENTAL PROCEDURES}

Although it is not widely accepted that the torsion test is the best one to estimate quantitively the hotworkability, we adopted it and also forging test. In forging tost, $\frac{1}{4} t$ hammor was uscd and the workability was estimated by the degree of cracking in the temperature range $1000^{\circ}-1300^{\circ} \mathrm{C}$. In torsion test, the specimen shown in Fig. I was kept at test temperatures for $30 \mathrm{~min}$, and then revolved with the speed of $100 \mathrm{rpm}$
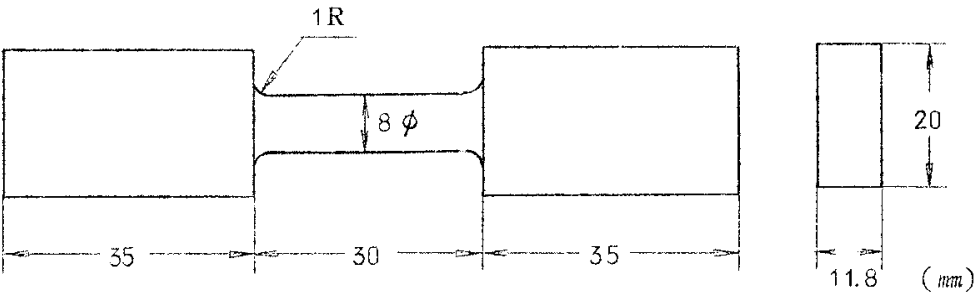

Fig.1. Size of specimen for hot-torsion test. until break.

Samples were melted by $250 \mathrm{~kg}$ electric arc furnace in open air(AM), by 20 and $100 \mathrm{~kg}$ vacuum induction furnaces (VIM), $50 \mathrm{~kg}$ vacuum arc remelting furnace (VAR), $50 \mathrm{~kg}$ electro-slag remelting furnace(ESR). In VIM, the alloys were refined at $1550^{\circ}-170000$ for 20 - $180 \mathrm{~min}$ under the vacuum pressure of $1-10^{-4} \mathrm{mmHg}$.

\section{EXPERIMENTAL RESULTS AND DISCUSSIONS}

Table 1 shows the chemical composition of samples. A - Y are Inconel 600 and HA - HL are Hastelloy X. Sample A was made by $250 \mathrm{~kg} \mathrm{AM,} \mathrm{B} \mathrm{by} \mathrm{ESR} \mathrm{from} \mathrm{row} \mathrm{material} \mathrm{A,}$ $\mathrm{C}$ by $100 \mathrm{~kg}$ VIM, D and E by VAR and ESR from row material C, F - O by VIM so as to examine the refining conditions __ temperature, time and vacuum, $P$ - X made by $20 \mathrm{~kg}$ VIM so as to examine the effect of alloying elements such as B, Be, Zr, and Ce etc.

1. H'f'ect of melting practices on the hot-workability

Fig.2 shows the relation between hot-workability and melting practices. These

alloys had almost the samo chomical composition and showed rather poorer hot-workabil- 
Table 1. Chemical composition of specimens

\begin{tabular}{|c|c|c|c|c|c|c|c|c|c|c|c|c|c|c|c|}
\hline Allo: & & C & Si & $\mathrm{Mn}$ & $\mathrm{Ni}$ & $\mathrm{Cr}_{\mathrm{r}}$ & $\mathrm{Cu}$ & $\mathrm{Fe}$ & $\mathrm{Ti}$ & 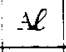 & Co & Mo & $\mathrm{W}$ & Others & Remarks \\
\hline \multirow{25}{*}{$\begin{array}{l}\text { INCUNEL } \\
600\end{array}$} & $A$ & 0.03 & 0.20 & 0.30 & 67.0 & 15.8 & 0.10 & 16.5 & 0.48 & 0.40 & $\left|\begin{array}{c}\mathrm{NO} \\
\mathrm{ADD}\end{array}\right|$ & $\left|\begin{array}{l}N 0 \\
\mathrm{ADD}\end{array}\right|$ & NO & & $\mathrm{AM}$ \\
\hline & B & 0.02 & 0.14 & 0.25 & 71.8 & 14.1 & '0.11 & 17.8 & 0.47 & 0.43 & $\begin{array}{l}\mathrm{NO} \\
\mathrm{ADD}\end{array} \mid$ & ADO & ADO & & $A M-E S R$ \\
\hline & C & 0.03 & 0.20 & 0.24 & 70.0 & 17.0 & 0.10 & 11.3 & 0.47 & 0.40 & $\begin{array}{l}\text { NO } \\
\mathrm{ADD}\end{array}$ & $\left|\begin{array}{l}\text { NO } \\
\text { ADD }\end{array}\right|$ & NO & & VIM \\
\hline & D & 0.03 & 0.20 & 0.20 & 75.0 & 15.5 & 0.10 & 7.2 & 0.40 & 0.40 & $\begin{array}{l}\mathrm{NO} \\
\mathrm{ADD}\end{array}$ & NO & NO & & $V I M-V A R$ \\
\hline & $E$ & 0.03 & 0.20 & 0.20 & 75.0 & 15.5 & 0.10 & 7.2 & 0.40 & 0.40 & NO & NO & NO & & VIM-ESR \\
\hline & F & 0.006 & 0.20 & 0.065 & 77.0 & 13.7 & 0.066 & 7.7 & $\mid \begin{array}{l}\text { NO } \\
\text { AID }\end{array}$ & $\begin{array}{l}\text { NO } \\
\text { ADD }\end{array}$ & $\begin{array}{l}N O \\
A D D\end{array}$ & $\begin{array}{l}N O \\
\mathrm{ADD}\end{array}$ & $\begin{array}{l}\text { NO } \\
\text { ADD }\end{array}$ & & $1550^{\circ} \mathrm{C} \times 60^{8} \times 10^{-4}$ \\
\hline & G & 0.002 & 0.18 & 0.020 & 77.8 & 127 & 0.022 & 7.8 & ADD & $\begin{array}{l}\text { No } \\
\text { AIDD }\end{array}$ & $\begin{array}{c}\mathrm{NO} \\
\mathrm{ADD}\end{array}$ & NO & NO & & $1550 \mathrm{C} \times 180 \times 10^{-4}$ \\
\hline & $\mathrm{H}$ & 0.002 & 0.19 & 0.150 & 77.8 & 14.1 & 0.086 & 7.2 & $\begin{array}{l}\text { No } \\
\text { ADD }\end{array}$ & $\begin{array}{l}\mathrm{NO} \\
\mathrm{ADD}\end{array}$ & ADD & $\begin{array}{l}\text { No } \\
A D D\end{array}$ & ADD & & $1625 \mathrm{C} \times 60^{\mathrm{O}} \times 10^{0}$ \\
\hline & I & $0.002 \mid$ & 3.19 & 0.038 & 76.5 & 13.6 & 0.047 & 6.9 & ND & $\left|\begin{array}{l}\mathrm{NO} \\
\mathrm{ADD}\end{array}\right|$ & $\begin{array}{l}\mathrm{NO} \\
\mathrm{ADD}\end{array}$ & $\mid \begin{array}{l}-\infty \\
A D D\end{array}$ & No & & $1625 \mathrm{C} \times 6 \mathrm{C} \times 10^{-2}$ \\
\hline & $J$ & 0.002 & 0.21 & 0.025 & 77.0 & 13.1 & 0.037 & 6.9 & $\begin{array}{l}\text { NO } \\
\text { ADD }\end{array}$ & $\begin{array}{l}\mathrm{NO} \\
\mathrm{ADD}\end{array}$ & $\mid$ & NO & ADD & & $1625 \mathrm{C} \times 60 \times 10^{-t}$ \\
\hline & $\mathrm{K}$ & 0.001 & 0.18 & 0.016 & 75.0 & 128 & 0.018 & 7.5 & ADD & $\begin{array}{l}\mathrm{NO} \\
\mathrm{ADD}\end{array}$ & $\left|\begin{array}{l}\mathrm{NO} \\
\mathrm{ADD}\end{array}\right|$ & $\left|\begin{array}{l}N O \\
A D D\end{array}\right|$ & NO & & $1625 \mathrm{C} \times 180^{\circ} \times 10^{-4}$ \\
\hline & $\mathrm{L}$ & 0.003 & 0.18 & $0.03 n$ & 75.7 & 132 & 10.044 & 7.0 & $\begin{array}{l}\mathrm{NO} \\
\mathrm{ADD}\end{array}$ & ND & $\left|\begin{array}{l}N O \\
A \perp D\end{array}\right|$ & $\mid \begin{array}{l}N O \\
A D D\end{array}$ & NOD & & $1700 \mathrm{C} \times 20 \times 10^{-4}$ \\
\hline & $\mathrm{M}$ & 0.001 & 0.20 & 0.095 & 77.0 & 13.7 & 0.069 & 6.5 & $\begin{array}{l}\text { No } \\
\mathrm{ADD}\end{array}$ & $\begin{array}{l}N O \\
A D D\end{array}$ & ADD & $\begin{array}{l}\mathrm{NO} \\
\mathrm{A} D \mathrm{D}\end{array}$ & ADD & & $1700^{\circ} \mathrm{C} \times 60 \times 10^{\theta}$ \\
\hline & $\mathrm{N}$ & 0.002 & 316 & u.uUs & 76.5 & 12.5 & 0.013 & 7.0 & $\begin{array}{l}N O \\
\text { ADD }\end{array}$ & $\left|\begin{array}{l}N O \\
A D D\end{array}\right|$ & NDD & NOD & ADD & & $1700 \mathrm{C} \times 60 \times 10^{-4}$ \\
\hline & 0 & 0.001 & 0.14 & 0.006 & 74.0 & 11.7 & 0.009 & 7.1 & $\begin{array}{l}\text { No } \\
\text { ADD }\end{array}$ & $\begin{array}{l}\text { NO } \\
\text { AND }\end{array}$ & $\mid$ & $\left|\begin{array}{l}\text { No } \\
\text { ADD }\end{array}\right|$ & ADD & & $1700 \mathrm{C} \times 180 \times 10^{-4}$ \\
\hline & $\mathrm{P}$ & 0.03 & 0.07 & 0.07 & 755 & 15.5 & ND & 8.0 & 0.40 & $\vdots 0.40$ & $\mid \begin{array}{l}\mathrm{NO} \\
\mathrm{ADD}\end{array}$ & $\begin{array}{l}\text { No } \\
\text { ADD }\end{array}$ & ND & $0.002 B$ & TIM \\
\hline & Q & 0.03 & 0.07 & 0.07 & 75.5 & 15.5 & ND & 8.0 & 0.40 & 0.40 & $\left|\begin{array}{l}\mathrm{N} O \\
\mathrm{ADD}\end{array}\right|$ & $\left|\begin{array}{l}\text { No } \\
\text { ADD }\end{array}\right|$ & $\begin{array}{l}\text { No } \\
\text { Ann }\end{array}$ & $.0007 \mathrm{~B}$ & VIM \\
\hline & $\mathrm{R}$ & 0.03 & 0.07 & 0.07 & 75.5 & 15.5 & ND & 80 & 0.40 & 0.40 & $\left|\begin{array}{l}\mathrm{NO} \\
\mathrm{ADD}\end{array}\right|$ & $\left|\begin{array}{l}x \\
\mathrm{ADD}\end{array}\right|$ & NO & $02 \mathrm{Be}$ & VIM \\
\hline & s & 0.03 & 0.07 & 0.07 & 75.5 & 15.5 & ND & 8.0 & 0.40 & 0.40 & $\stackrel{N O}{A D D}$ & $\begin{array}{l}N D \\
A D D\end{array}$ & NO & $0.07 \mathrm{Bc}$ & VIM \\
\hline & $\mathrm{T}$ & 0.03 & 0.07 & 0.07 & 75.5 & 155 & $\mathrm{ND}$ & 8.0 & 0.40 & 0.40 & $\mid \begin{array}{l}\mathrm{NO} \\
\mathrm{ADD}\end{array}$ & No & AD & $0.02 \mathrm{Zr}$ & VIM \\
\hline & $\mathrm{L}^{-}$ & 0.03 & 0.07 & 0.07 & 75.5 & 15.5 & ND & 8.0 & 0.40 & 0.40 & $\begin{array}{l}N O \\
A D D\end{array}$ & $\mid \begin{array}{l}\text { NO } \\
\text { AnD }\end{array}$ & $\stackrel{N O}{A D D} \mid$ & $0.07 \mathrm{Zr}$ & VIM \\
\hline & $r$ & 0.03 & 0.07 & 0.07 & 75.5 & 155 & iND & 8.0 & 0.40 & $0.40 \mid$ & $\left|\begin{array}{c}\mathrm{N} D \\
\mathrm{ADD}\end{array}\right|$ & $\begin{array}{l}\text { NO } \\
\text { ADD }\end{array}$ & NO & $0.007 \mathrm{~B}^{-0.07 \mathrm{Be}}$ & $V I M$ \\
\hline & W & 0.03 & 0.07 & 0.07 & 755 & 15.5 & ND & 8.0 & 0.40 & 0.40 & : & $\left|\begin{array}{l}\mathrm{NO} \\
\mathrm{ADD}\end{array}\right|$ & $\begin{array}{l}\mathrm{NO} \\
\mathrm{ADD}\end{array} \mid$ & $0.007 \mathrm{~B}-0.07 \mathrm{Zr}$ & VIM \\
\hline & $\mathrm{x}$ & 0.03 & 0.07 & 0.07 & 755 & 15.5 & ND & 8.0 & 0.40 & 0.40 & $\underset{\mathrm{ADD}}{\mathrm{N}}$ & $\begin{array}{l}N D \\
A D D\end{array}$ & NO & $0.007 \mathrm{~B}-0.07 \mathrm{Ce}$ & VIM \\
\hline & $\mathrm{Y}$ & 0.04 & 0.15 & 0.03 & $75.5 \mid$ & $\mid 15.5$ & $<0.01$ & 6.8 & 0.40 & 0.40 & : & $\begin{array}{l}\mathrm{NO} \\
\mathrm{ADD}\end{array}$ & $\begin{array}{l}\mathrm{N} O \\
\mathrm{ADD}\end{array}$ & - & $A M$ \\
\hline \multirow{12}{*}{$\begin{array}{l}\text { HASTE- } \\
\text { LLOY - } x^{*}\end{array}$} & HA & 0.07 & 0.26 & 0.75 & $\mathrm{Bab}$ & 21.0 & ND : & 19.4 & $\left|\begin{array}{l}\text { No } \\
\text { ADD }\end{array}\right|$ & $\mathrm{AD}$ & 1.3 & 8.3 & 0.7 & $0.003 \mathrm{~B}$ & VIM \\
\hline & $\mathrm{HB}$ & 0.07 & 0.26 & | 0.75 & $\mathrm{Ba} e$ & 21.0 & ND & 19.4 & $\left|\begin{array}{l}\text { No } \\
\mathrm{ADD}\end{array}\right|$ & ADD & 1.3 & 8.3 & 0.7 & $0.007 \mathrm{~B}$ & VIM \\
\hline & $\mathrm{HC}$ & 0.07 & 0.26 & 0.75 & $\mathrm{Ba}$ & 21.0 & ND & 19.4 & NO & NO & 1.3 & 8.3 & 0.7 & $0.003 \mathrm{~B}-0.03 \mathrm{Be}$ & VIM \\
\hline & $\mathrm{HD}$ & 0.07 & 026 & 0.75 & $\mathrm{Ba}$ & 21.0 & ND & 19.4 & $\left|\begin{array}{l}\text { No } \\
\text { ADD }\end{array}\right|$ & AD & 1.3 & 8.3 & 0.7 & $0.003 \mathrm{~B}-0.08 \mathrm{Be}$ & VIM \\
\hline & $\mathrm{HE}$ & 0.07 & 0.26 & 0.75 & $\mathrm{Ba} \ell$ & 21.0 & ND & 19.4 & $\mid \begin{array}{l}\text { No } \\
\text { ADD }\end{array}$ & $\begin{array}{l}N D \\
A D D\end{array}$ & 1.3 & 8.3 & 0.7 & $0.003 \mathrm{~B}-0.035 \mathrm{Zr}$ & VIM \\
\hline & $\mathrm{HF}$ & 0.07 & 0.26 & 0.75 & $\mathrm{Ra}$. & 21.0 & ND & 19.4 & $\mid \begin{array}{l}\text { No } \\
\text { ADD }\end{array}$ & $\begin{array}{l}\text { No } \\
\text { ADD }\end{array}$ & 1.3 & 8.3 & 0.7 & $\cap n \cap z_{B}-n \cap 9 Z_{I}$ & VIM \\
\hline & $\mathrm{HG}$ & 0.07 & 0.26 & 0.75 & $\mathrm{Bal}$ & 21.0 & ND & 19.4 & $\left|\begin{array}{l}N 0 \\
\mathrm{ADD}\end{array}\right|$ & $\begin{array}{l}\text { No } \\
\text { AnD }\end{array} \mid$ & 1.3 & 8.3 & 0.7 & $0.003 \mathrm{~B}-0.035 \mathrm{Ce}$ & VIM \\
\hline & $\mathrm{HH}$ & 0.07 & 0.26 & 0.75 & $\mathrm{Ba} b$ & 21.0 & ND & 19.4 & $\mid \begin{array}{l}\text { No } \\
\text { AIDD }\end{array}$ & $\begin{array}{l}\mathrm{NO} \\
\mathrm{ADD}\end{array}$ & 1.3 & 8.3 & 0.1 & $0.003 \mathrm{~B}-0.09 \mathrm{Ce}$ & VIM \\
\hline & $\mathrm{HI}$ & 0.07 & 0.26 & 0.75 & $\mathrm{Bab}$ & 21.0 & ND & 19.4 & $\begin{array}{l}\mathrm{NO} \\
\mathrm{ADD}\end{array}$ & $\begin{array}{l}\text { No } \\
\text { ADI }\end{array}$ & 1.3 & 8.3 & 0.7 & $\begin{array}{l}0.003 \mathrm{~B}-0.035 \mathrm{Z} \mathbf{r} \\
-0.03 \mathrm{Be}\end{array}$ & VIM \\
\hline & $\mathrm{HJ}$ & 0.07 & 0.26 & 0.75 & $\mathrm{Ba} \ell$ & 21.0 & $\mathrm{ND}$ & 19.4 & $\left|\begin{array}{l}N O \\
A D D\end{array}\right|$ & $\begin{array}{l}\text { No } \\
\text { ADD }\end{array}$ & 1.3 & 8.3 & 0.7 & $\begin{array}{l}0.003 \mathrm{~B}-0.035 \mathrm{Ce} \\
-0.03 \mathrm{Be}\end{array}$ & VIM \\
\hline & $\mathrm{HK}$ & 0.07 & 0.26 & 0.75 & $\mathrm{Ba}$ & 21.0 & ND & 19.4 & $\left|\begin{array}{l}\text { NO } \\
\text { ADO }\end{array}\right|$ & NO & 1.3 & 8.3 & 0.7 & $\begin{array}{l}0.003 B^{-0.035 C e} \\
-0.055 \mathrm{z}\end{array}$ & VIM \\
\hline & $\mathrm{HL}$ & 0.07 & 0.26 & 0.75 & $\mathrm{Ba}$ & 21.0 & $\mathrm{ND}$ & 19.4 & $\mid \begin{array}{l}\text { No } \\
\text { AnD }\end{array}$ & \begin{tabular}{|l|} 
NO \\
ADD
\end{tabular} & 1.3 & 8.3 & 0.7 & $\begin{array}{l}0.003 \mathrm{~B}-0.035 \mathrm{Ce} \\
0.003 \mathrm{Be}-0.035 \mathrm{Z} \mathrm{r}\end{array}$ & VIM \\
\hline
\end{tabular}


ity. This fact may be explained by the higher content of $\mathrm{Cu}, \mathrm{Mn}$ and Fe as explained later. The increase of hotworkability of alloys made by VAR and ESR may by explained by the finer casting structure because of their higher cooling rate and the decrease of $P$ and $S$ as indicated by Kelley (4).

2. Effect of vacuum melting conditions Fig. 3 shows the effect of the refining temperature and time on the hot-workability under the vacuum pressure of $10^{-4} \mathrm{mmHg}$. Fig. 4 shows the effect of vacuum pressure at refining conditions of $1625^{\circ}$, $1700^{\circ} \mathrm{C}$ for $60 \mathrm{~min}$. The higher the refining temperature, the longer the refining time and the higher the vacuum, the better the hot-workability. This fact may be explained by the decrease of some detrimental elements by vaporization, gas components and inclusions. Under vacuum, $\mathrm{C}, \mathrm{Mn}$, and $\mathrm{Cu}$ decreased much, and other elements such as $\mathrm{Si}, \mathrm{P}, \mathrm{S}, \mathrm{Ni}, \mathrm{Fe}, \mathrm{N}, \mathrm{H}, \mathrm{As}, \mathrm{Sb}$, Sn, and O changed little. Fig. 5 shows the effect of Cu plus $\mathrm{Mn}$ on the hot-workability which decreased as Cu and Mn increased. In the course of forging, the materials containing higher $\mathrm{Cu}$ and Mn, cracked on the surface and at the corner of forged ingots. All cracks were along $\gamma$ grain boundaries. Fig. 6 shows the results of EPMA analysis of the extreme of a crack. It was ascertained that $\mathrm{Cu}$ and $\mathrm{Mn}$ segregated on $\boldsymbol{\gamma}$ grain boundaries. The segregation may be the reason of the poorer hot-workabiliby. It could be decreased by the diffusion-annealing as explained later.

Fig. 7 shows the effect of inclusims on the number of revolutions in Inconel 600 and Hastelloy X. In Inconel 600, the number increased as the inclusion content decreased, but in Hastelloy $X$ this relation was not clear, perhaps because of the too low level of hotworkability. In both alloys, the inclusions were round, Si-rich and type categoly C. Fig. 8 shows the effect of oxygen content on the hot-workability in Inconel 600, where no clear relation was observed.

Fig. 9 shows the effect of Si. As

Si content decreased, the inclusion

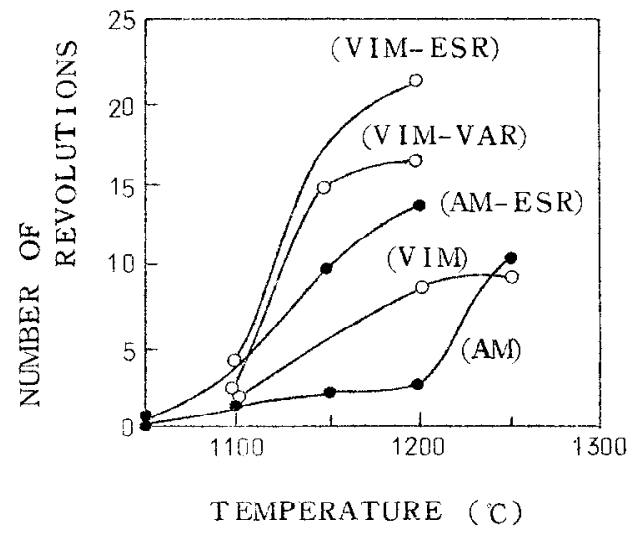

Fig.2. Effect of melting practices on the hot-workability in Inconel 600 .

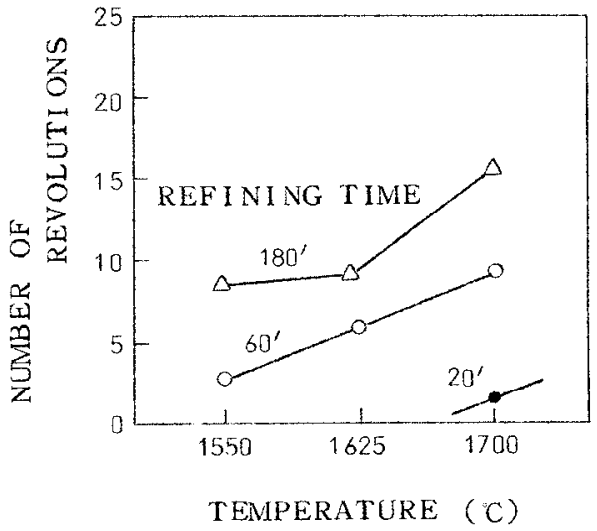

Fig.3. Effect of refining temperature, time under $10^{-4} \mathrm{mmHg}$ on the hot-workability in Inconel 600 .

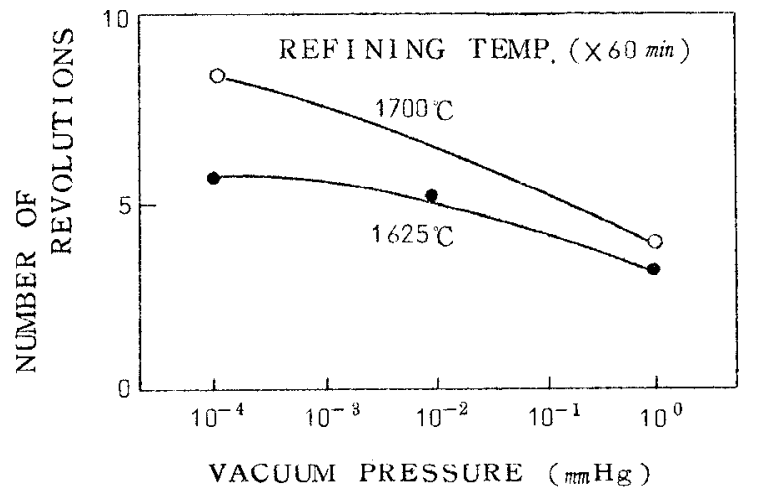

Fig.4. Effect of vacuum pressure during vacuum refining on the hotworkability in Inconel 600. 
content decreased and the hotworkability increased. From the above experimental results, it can be said that the detrimental elements to hot-workability were Cu, Mn, of which effect was through grain boundaries, and Si, through inclusions. Savage et al. Indicated also harmful effect of $\mathrm{Mn}$ and $\mathrm{Si}(5)$.

Next, will be discussed the effect of casting structure and $\gamma$ grain size on the hot-workability. In the as-cast condition, as Fig.lo shows, alloys almost broke along the primary $\gamma$ grain boundaries, so that alloys having the finest macro-structure showed the highest hotworkability. Fig.ll shows the macro-structures of alloys made by different melting practices.

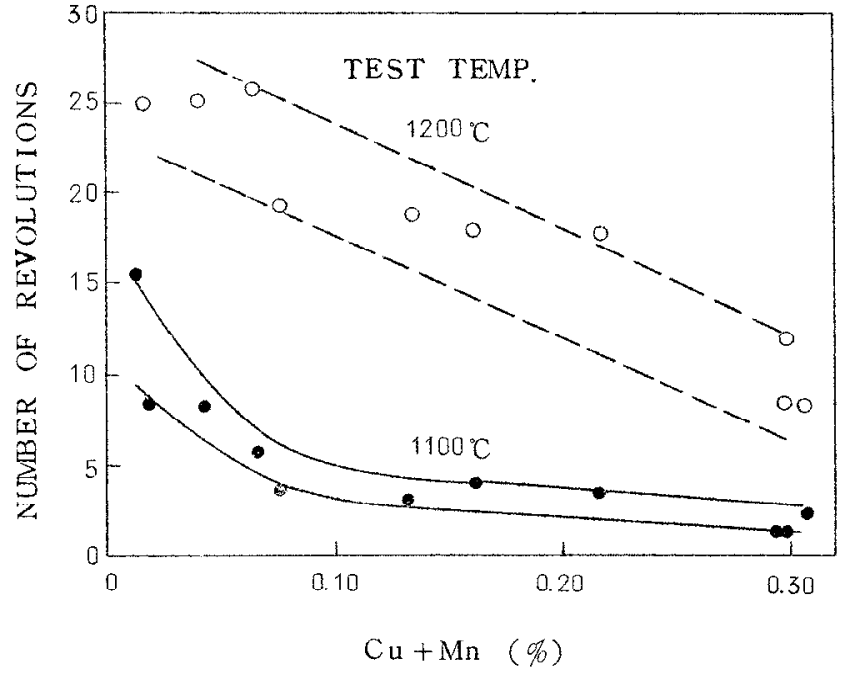

Fig.5. Effect of $\mathrm{Cu}$ and $\mathrm{Mn}$ content on the hot-workabiLity in Incone $\perp 600$ made by $V \perp M$.
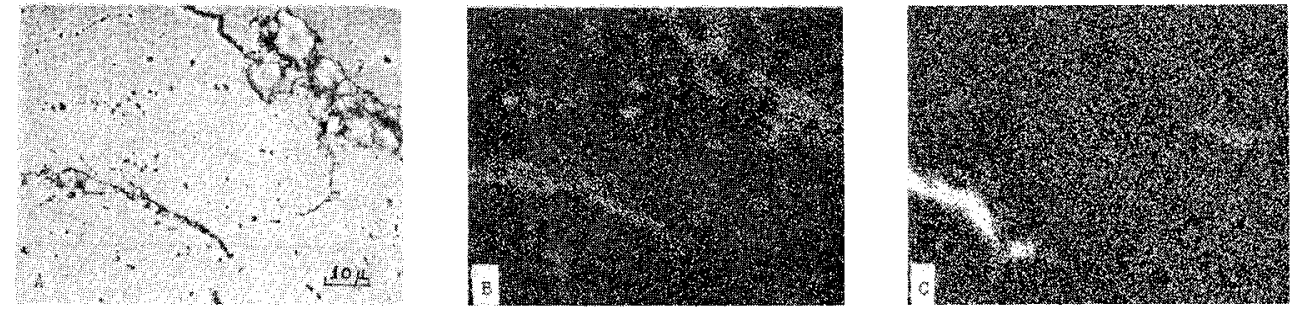

Fig.6: Elemental X-ray images of the extreme of crack in forged Inconel 600. A: Sample current C: $M n-K \alpha$ $B: S-K \alpha$
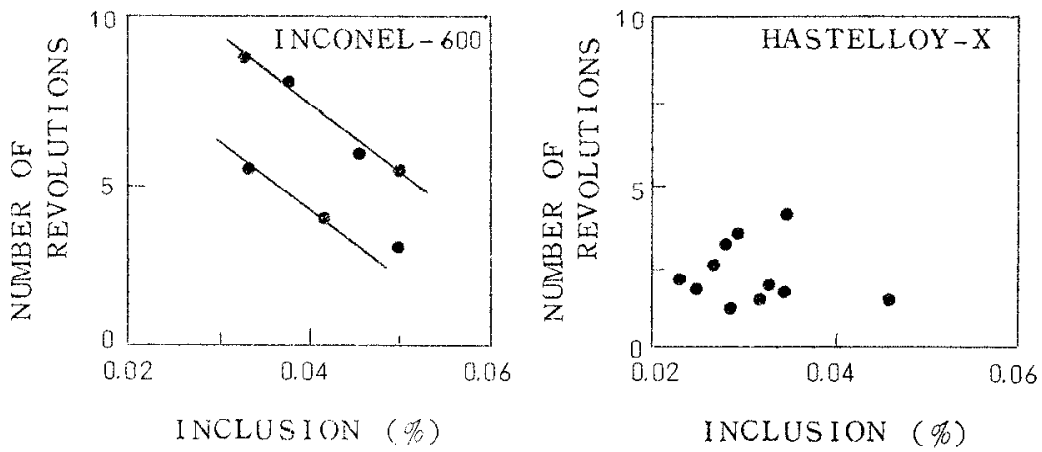

Fig.7. Effect of inclusion content on the hot-workability at $1100^{\circ} \mathrm{C}$ in Inconel 600 and Hastelloy $X$ made by VIM. 
It may be pointed out that ESR was the bost procoss in this regard. One primary $\gamma$ grain is divided into several sub-grains. Fig.12-(a) shows the relation between the surface area of subgrain boundaries and the hot-workability. The correlation is not clear if the points of fine primary $\gamma$ grains are omitted. Hence it can be said that the sub-grain size is not important for the hot-workability. The segregation on boundaries can be detected by EPMA. There were highly segregated boundaries and less segregated ones. The former may correspond to the primary $\gamma$ grain boundaries.

After forging, $\gamma$ grains become much finer and the relation between the surface area of $\gamma$ grain boundaries and the hot-workability is clearly recognized as shown in Fig.I2-(b). In this case, the weak planes in as-cast conaition _ the primary $\gamma$ grain boundaries where the detrimental elements segregale much during solidification _- may be smothered, and $\gamma$ grain boundarics produced by recrystallization become instead the weakest planes.

Fig.13 shows the cross section of fractured surface of forged-specimens having coarse or fine grains. In the coarse grain size specimen, there was observed almost no deformation of $\gamma$ grains, on the other hand in the small grain size specimen, the grain were fairly deformed before cracking.

Perhaps one of reasons may be the fine grain specimen has higher elongation at high temperature. Anyhow, both specimens broke out along the $\gamma$ grain boundaries.

\section{Effect of minor elements}

As explained already, grain boundaries had a decisive influence on the hot-workability. Fig.14-(a) and (b) show the hot-workability of Inconel 600 and Hastelloy $X$, when at lcast ono of $B$, $\mathrm{Zr}$, and $\mathrm{Ce}$ was added as minor elements. In every alloy to which $\mathrm{B}, \mathrm{Be}$ and/or $\mathrm{Zr}$ were addea, the hot-workability was improved. Especially the combination of Ce-Be-Zr was effective. It may be very difficult to clarify the real function of these elements. K.H. Decker et al. pointed out that B and Zr impede the

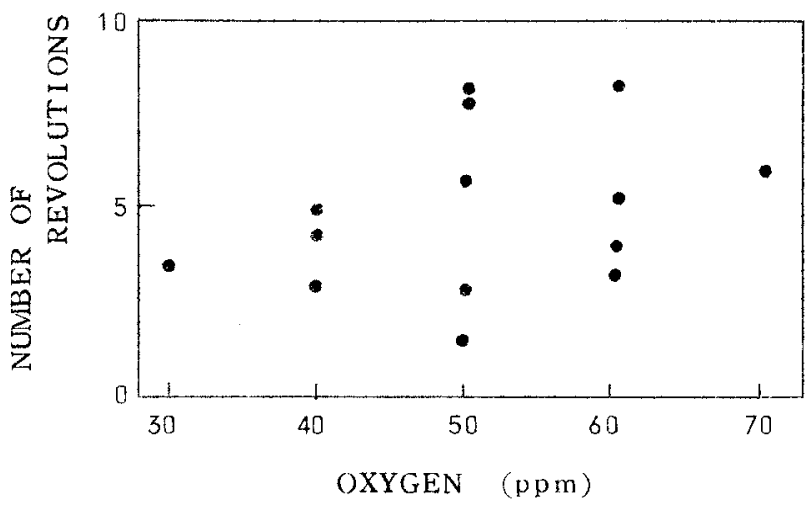

Fig.8. Effect of oxygen content on the hot-workability at $1100^{\circ} \mathrm{C}$ in Inconel 600 made by VIM.

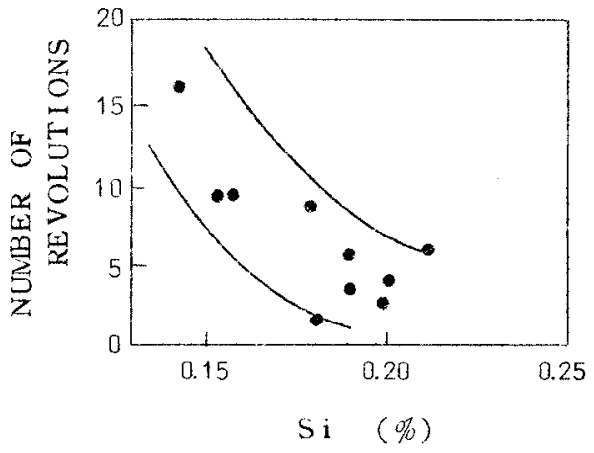

Fig.9. Effect of Si content on the hotworkability in Inconel 600 made by VIM.

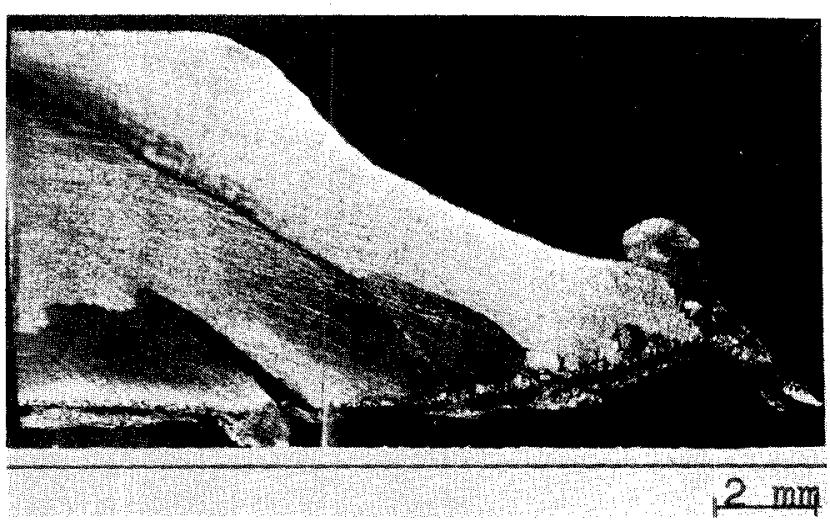

Fig.10. Cross section of a fractured specimen. Cracks were observed, propagating along the primary grain boundaries. 

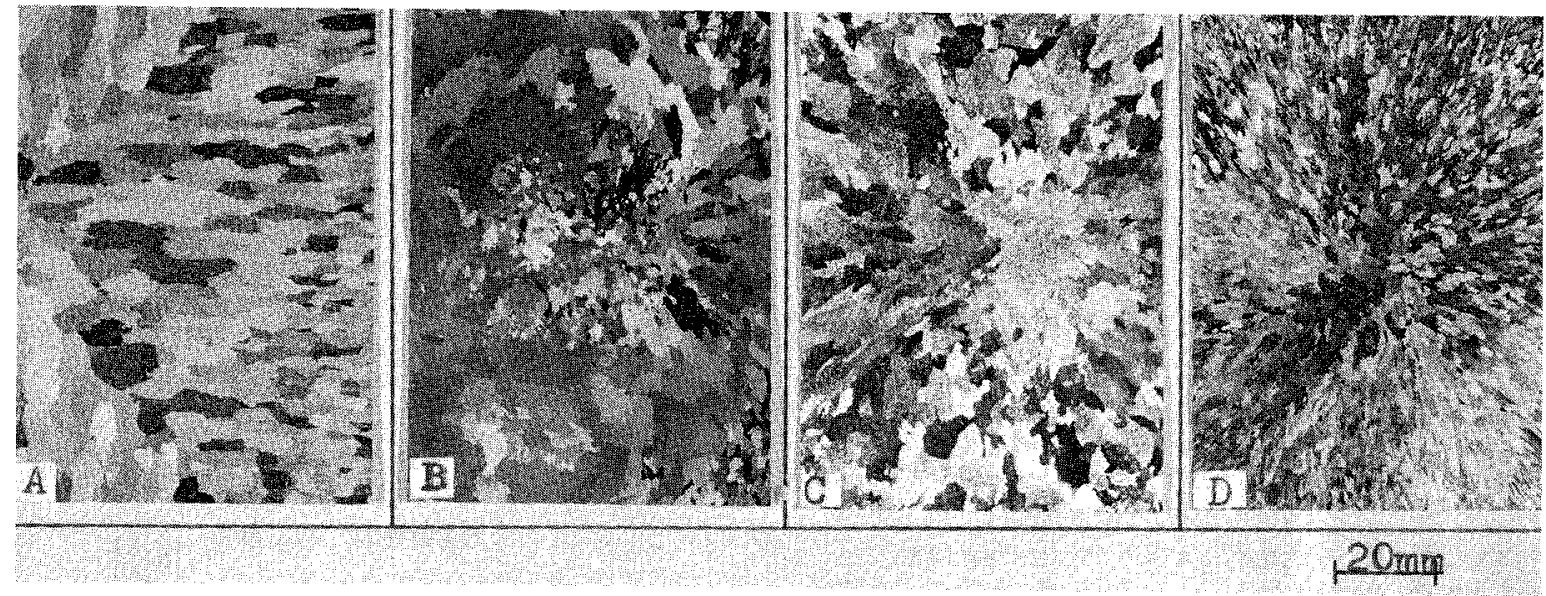

(a) AM

(b) VIM

(c) VAR

(d) ESR

Fig.ll. Effect of melting practices on macro-structures.

segregation of detrimental elements on grain boundaries (6). Fig. 15 shows the distribution of $B$ disclosed by fission track method in as-cast condition of Inconel 600 in the case of B, B-Be and $B-Z r$ additions. In these photographs, the segregation of $B$ on grain boundarics or sometimes on sub-grain boundaries is clearly recognized, especial.7y in B-7.r added alloy, which showed the best hotworkability.

\section{Diffusion-annealing and hot-worka- bility \\ As already indicated, the segrega-} tion on grain boundaries seems to control the hot-workability, so that the diffusion-annealing which makos segregated impurities diffuse into grains, may be effective to the improvement of hot-workability. Fig.16 shows the effect of diffusion-annealing on the hot-workability in Inconel 600. As the annealing time increased, the segregation decreased as shown in $\mathrm{H}^{\prime} \mathrm{ig} .17$, and the hot-workability was also improved.

Fig.18 shows the torsion tesl result of air-melted Inconel 600 having the improved chemical composition _ low Si, Mn and Cu.

\section{CONCLUSIONS}

The factors which control the hotworkability of Inconel 600 and Hastelloy $X$ were investigated and it was clarified that the following factors improved the
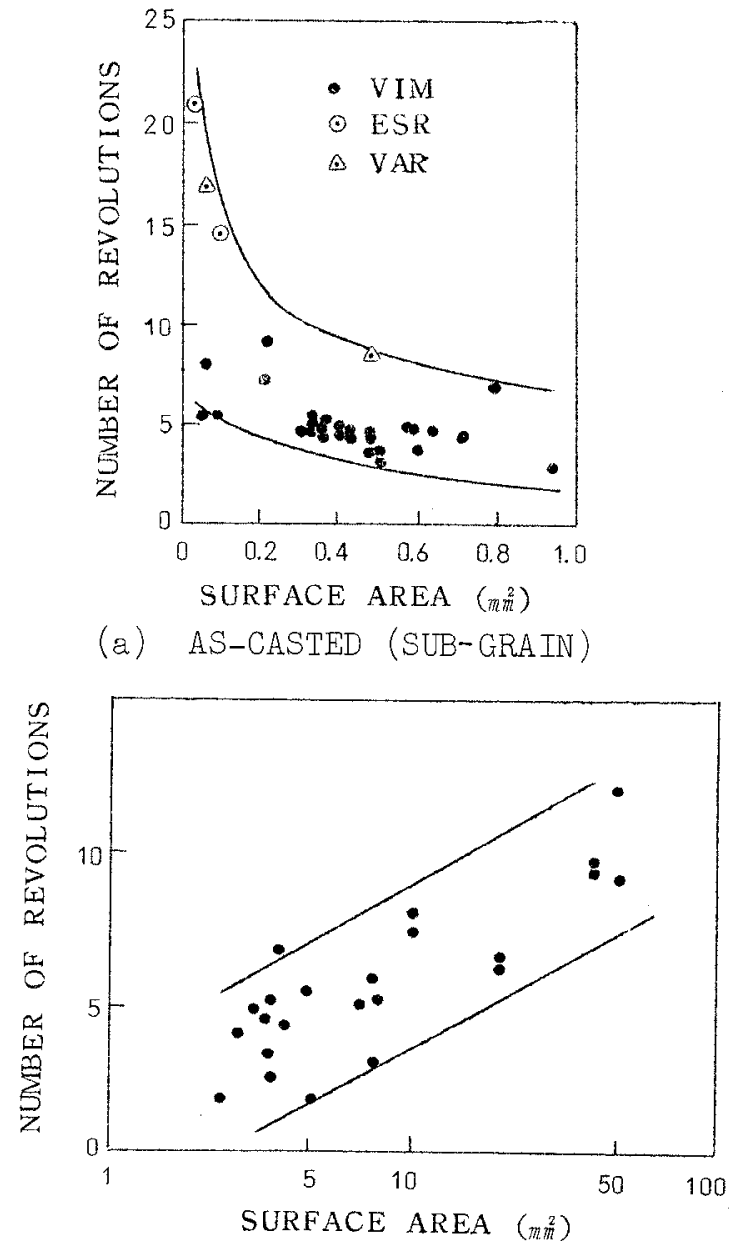

(b) AS-FORGED ( $\gamma$ GRAIN)

Fig.l2. Effect of the total surface area of grain boundaries in the unit volume on the hot-workability at $1200^{\circ} \mathrm{C}$ in Inconel 600. 


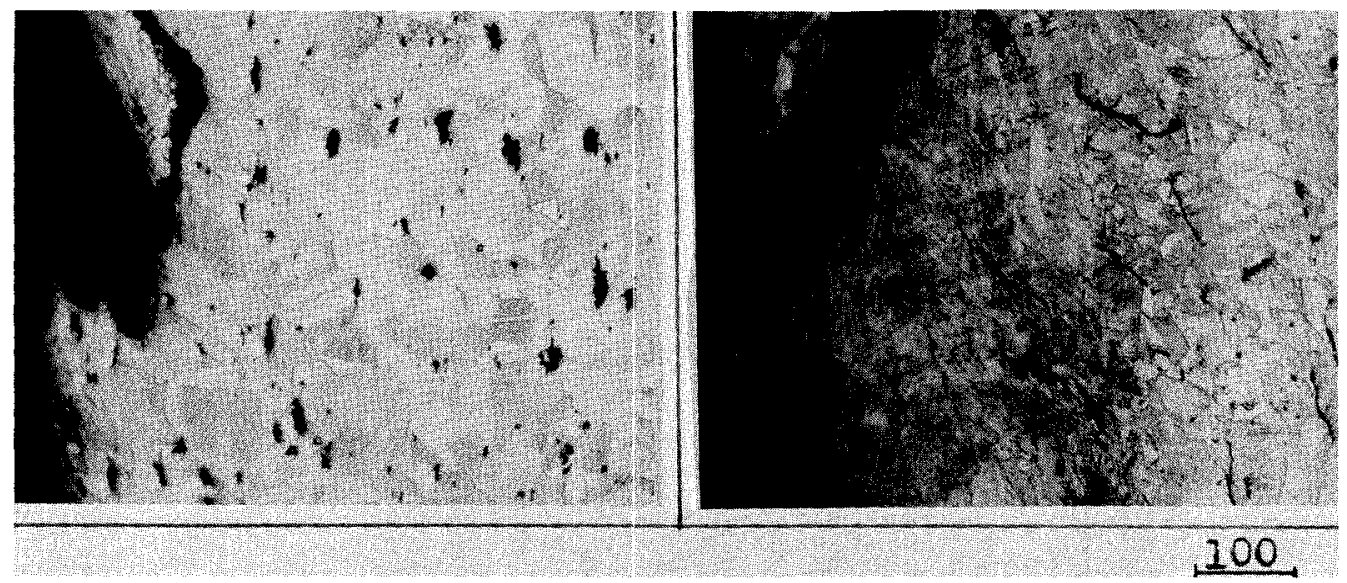
(a) COARSE G.S.
(b) FINE G.S.

Fig.13. Cross section of fractured surfaces of coarse and fine grain size specimens of forged Inconel 600 in hot-torsion test.

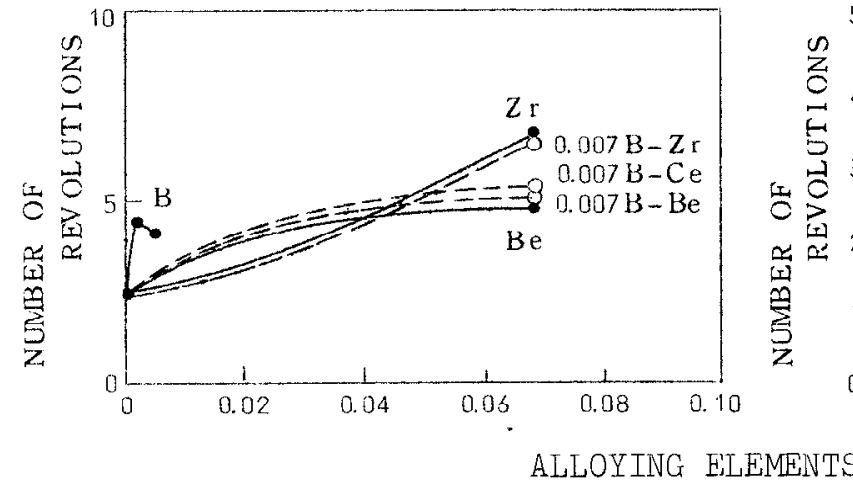

(a) Inconel $600,1100^{\circ} \mathrm{C}$

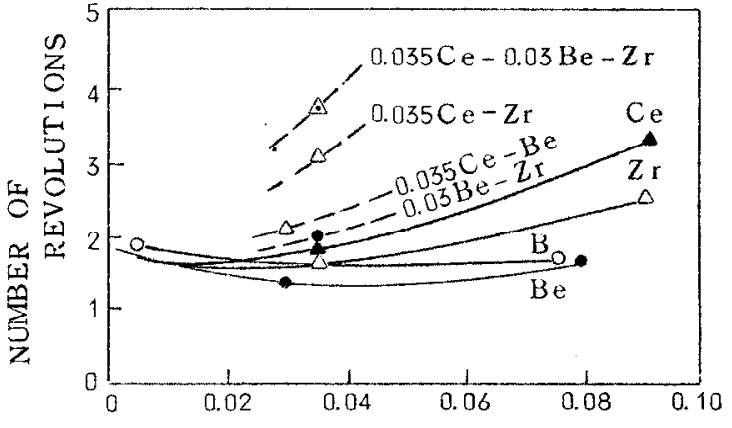

$(\%)$

Fig.14. Effect of minor alloying elements on the hot-workability in as-casted Inconel 600 and Hastelloy $X$.

hot-workability.

\section{MECHANISM}

(1) Decrease of $\mathrm{Cu}$ and $\mathrm{Mn}$ content.

(2) Addition of minor elements such as B, Be, $\mathrm{Zr}$, and Ce etc.

(3) Decrease of inclusions.

(4) Decrease of $\gamma$ grain size.

\section{PROCESS}

(1) Electro-slag remelting.

(2) Refining at high temperature for long time under high vacuum.

(3) Diffusion-annoaling under the time and temperature conditions where $\gamma$ grain size does't grow too much.

(4) Increase of forging ratio. 


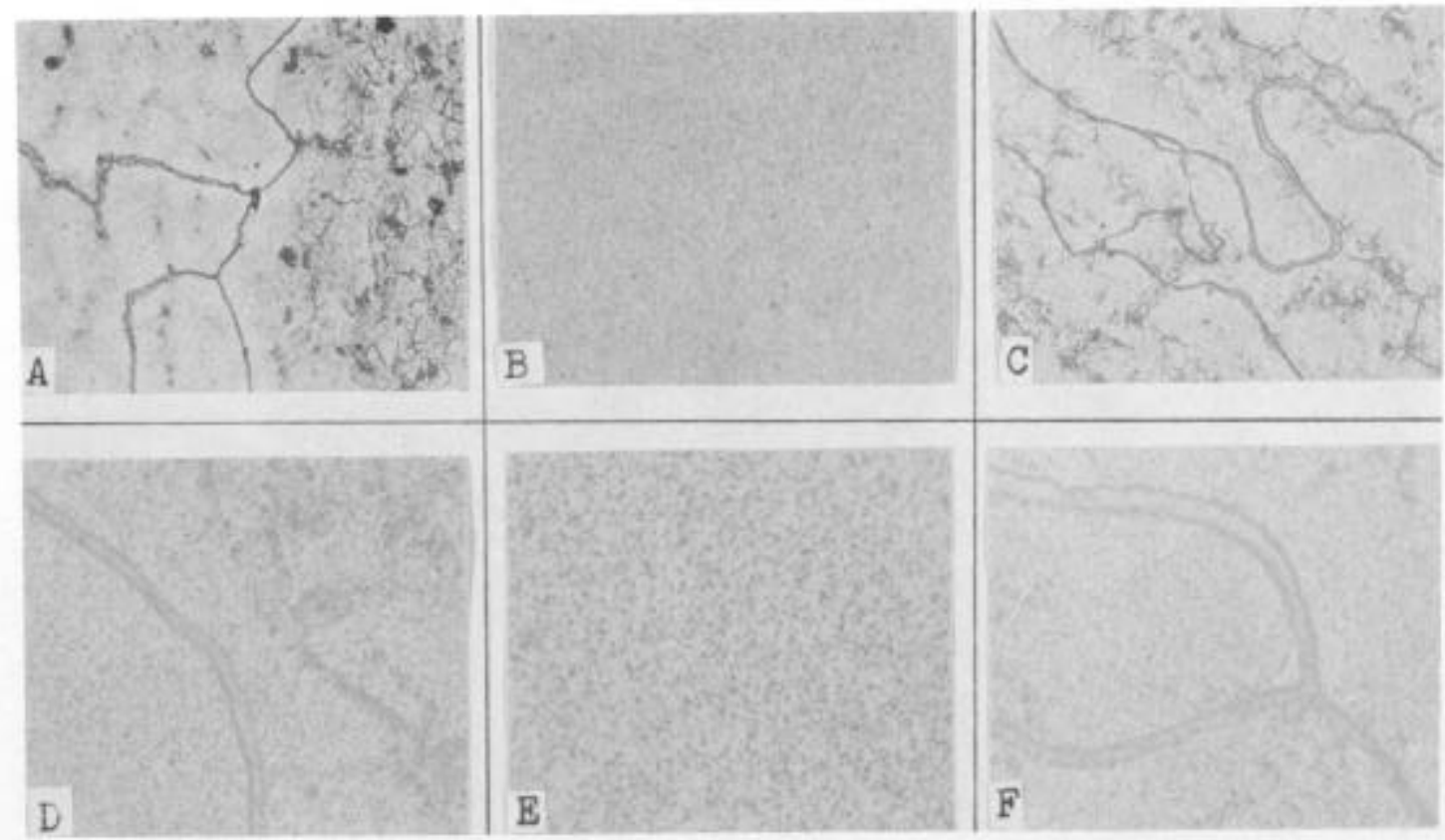

Fig.15. Distribution of B disclosed by fission track etching method in B-added Incone1 600 .

$A$ and $D$ : $B$

$B$ and $E$ : $B-B e$

$\mathrm{C}$ and $\mathrm{F}: \mathrm{B}-\mathrm{Zr}$
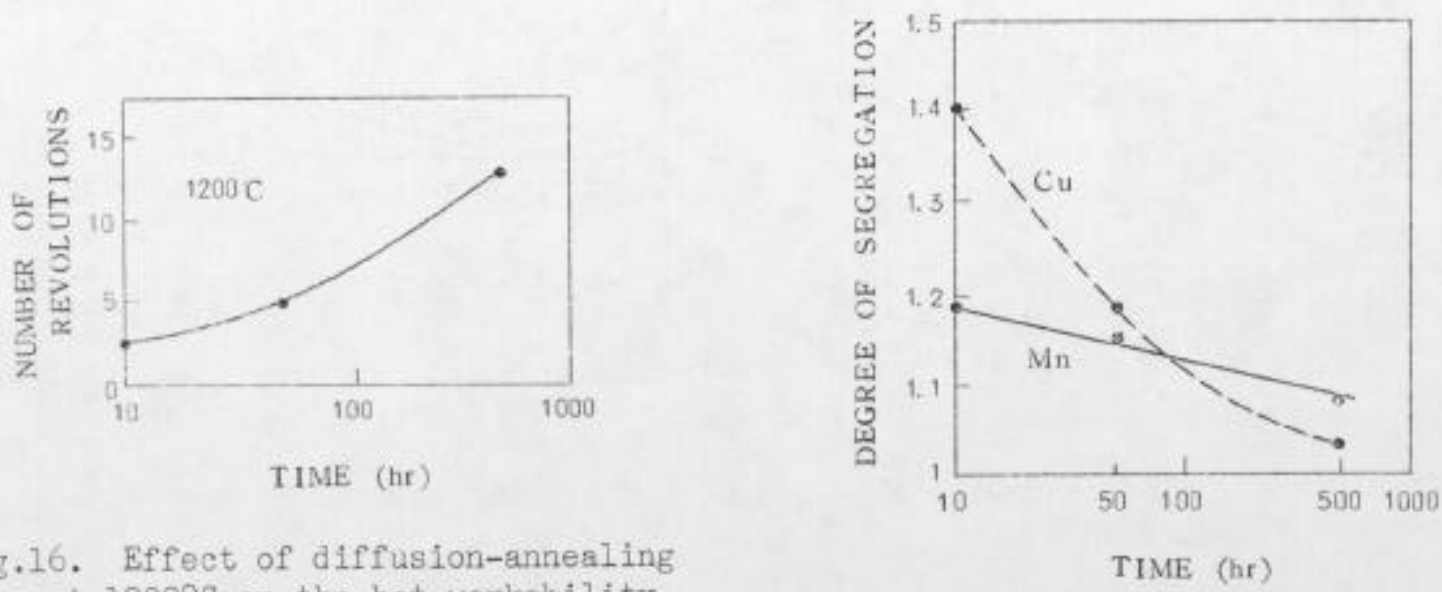

Fig.16. Effect of diffusion-annealing time at $1200^{\circ} \mathrm{C}$ on the hot-workability in air-melted and as-casted Inconel 600 .

Fig.17. Bffect of diffusion-annealing time at $1200^{\circ} \mathrm{C}$ on the segregation on $\gamma$ grain boundaries.

\section{ACKNOWLEDGEMENT}

The authors are very grateful to Dr. S. Dazai, Ex-director of Research Institute for his advices and encouragements throughout the works, to Dr. Y. Nakamura for his melting practices and to $\mathrm{Mr}$. A. Murota who helped us to carry out the experiments.

\section{PEFERENCES}

1. The Japan Institute of Metals: Strength and Fracture of Metallic Materials (1964), p491, Maruzen

2. R. Kiessling: J. Met., 22, (1969), p48 - 52 
3. ASTM: Effects of Residual Elements on Froperties of Austenitic. Stainless Steel. STP (1967), p418

4. E. W. Kelley: Met. Eng. Quart., plo $-16$

5. W. F. Savage and B. M. Krants: Wolding J. Suppl., 50, (1971), p292 $-303$

6. R. F. Decker: Steel Strengthening Mechanisms Symposium (Zurich), (1969)

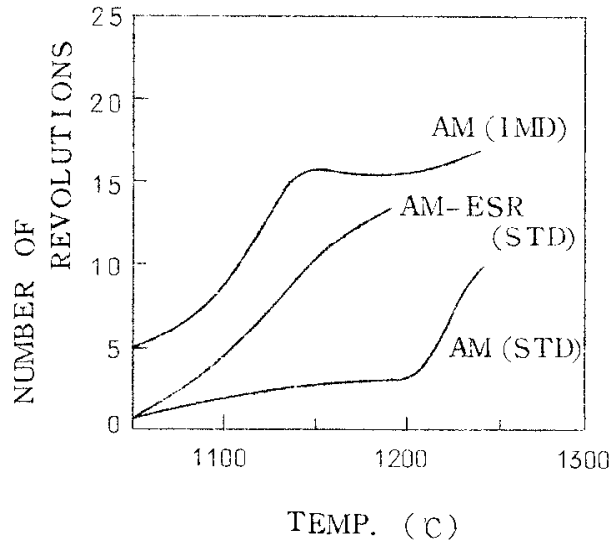

Fig.18. Hot-workability of Ineonel 600 of standard composition (STD) and improved composition (IMP). 